\title{
Concentration Levels and Potential Ecological Risks of Polycyclic Aromatic Hydrocarbons in Chinese Rivers
}

\author{
Chenglian Feng • Qian Luo · Zijian Wang
}

Received: 8 December 2008 / Revised: 3 February 2009 / Accepted: 10 February 2009 / Published online: 4 March 2009

(C) Springer Science+Business Media B.V. 2009

\begin{abstract}
Polycyclic aromatic hydrocarbons (PAHs) are one of the most important persistent organic pollutants (POPs) and are widespread in surface waters in China. Based on the literature surveyed, concentration levels and geographic distribution of $16 \mathrm{PAHs}$ in major Chinese rivers were summarized. The results showed that 2-3-ring PAHs were predominated in water, 4-ring PAHs were abundant in suspended particular matter (SPM), and 3-6 ring PAHs were the main chemical forms in sediment. In general, concentration levels of PAHs in rivers from northern China were higher than those from southern China. There existed a significant difference between concentration level of PAHs from the north and from the south. In comparison with concentration levels of PAHs in the world rivers, level of PAHs in dissolved phase in Chinese rivers was higher than those from other countries, while PAHs concentration in SPM and sediment of Chinese rivers was in the middle range. The quotient method was used to screen the potential risk of PAHs to aquatic organisms. It appeared that 7 among 16 PAHs, i.e., phenanthrene, anthracene, fluoranthene, pyrene, benzo[a]anthracene, chrysene and benzo[a]pyrene, might have potential adverse effects to aquatic system, which should be particularly concerned.
\end{abstract}

Keywords Polycyclic aromatic hydrocarbons (PAHs) . Chinese rivers · Concentration level · Geographic distribution $\cdot$ Ecological risk

C. Feng $\cdot$ Q. Luo $\cdot$ Z. Wang $(\bowtie)$

State Key Laboratory of Environmental Aquatic Chemistry, Research Center for Eco-Environmental Sciences, Chinese Academy of Sciences, P.O. Box 2871, Beijing 100085, China e-mail: wangzj@rcees.ac.cn

\section{Introduction}

Polycyclic aromatic hydrocarbons (PAHs) are a class of diverse organic compounds which mainly contain two or more fused aromatic rings of carbon and hydrogen atoms. As one of the typical persistent organic pollutants (POPs), $\mathrm{PAHs}$ are widely distributed in various environmental media which occur in atmosphere, water, soil, sediment and organism (Tao et al. 2004; Nizzetto et al. 2008). The 16 PAHs have been listed as priority control pollutants by US Environmental Protection Agency (Manoli et al. 2000). Due to their toxic, mutagenic and carcinogenic characteristics, PAHs are considered to be hazardous to the biota and surrounding environment. The primary environmental sources of PAHs include both anthropogenic inputs and biological conversion of biogenic precursors (Means et al. 1980). PAHs can enter into the environment through various routes. Fossil fuel incomplete combustion, oil spills, domestic and industrial wastewater discharges, as well as atmospheric fallout of vehicle exhaust and industrial stack emission, have caused significant accumulation of PAHs in aquatic environment (Broman et al. 1991; Na"f et al. 1992; Countway et al. 2003; Gu et al. 2003; Fang et al. 2007). For environmental management, understanding the behavior of PAHs and their environmental risk to ecological systems, especially for aquatic environment, is necessary.

Organic contaminants in aquatic system may exist in several forms, including free dissolved phase, the phase bounded to dissolved organic matter (DOM), adsorbed to suspended particulate matter (SPM), and associated with sediments (Zhou and Maskaoui 2003). The distribution of PAHs in aquatic multimedia is mainly controlled by their intrinsic physical-chemical properties, such as solubility, vapor pressure and adsorption coefficient. The environmental fate and behavior of PAHs are ultimately determined 


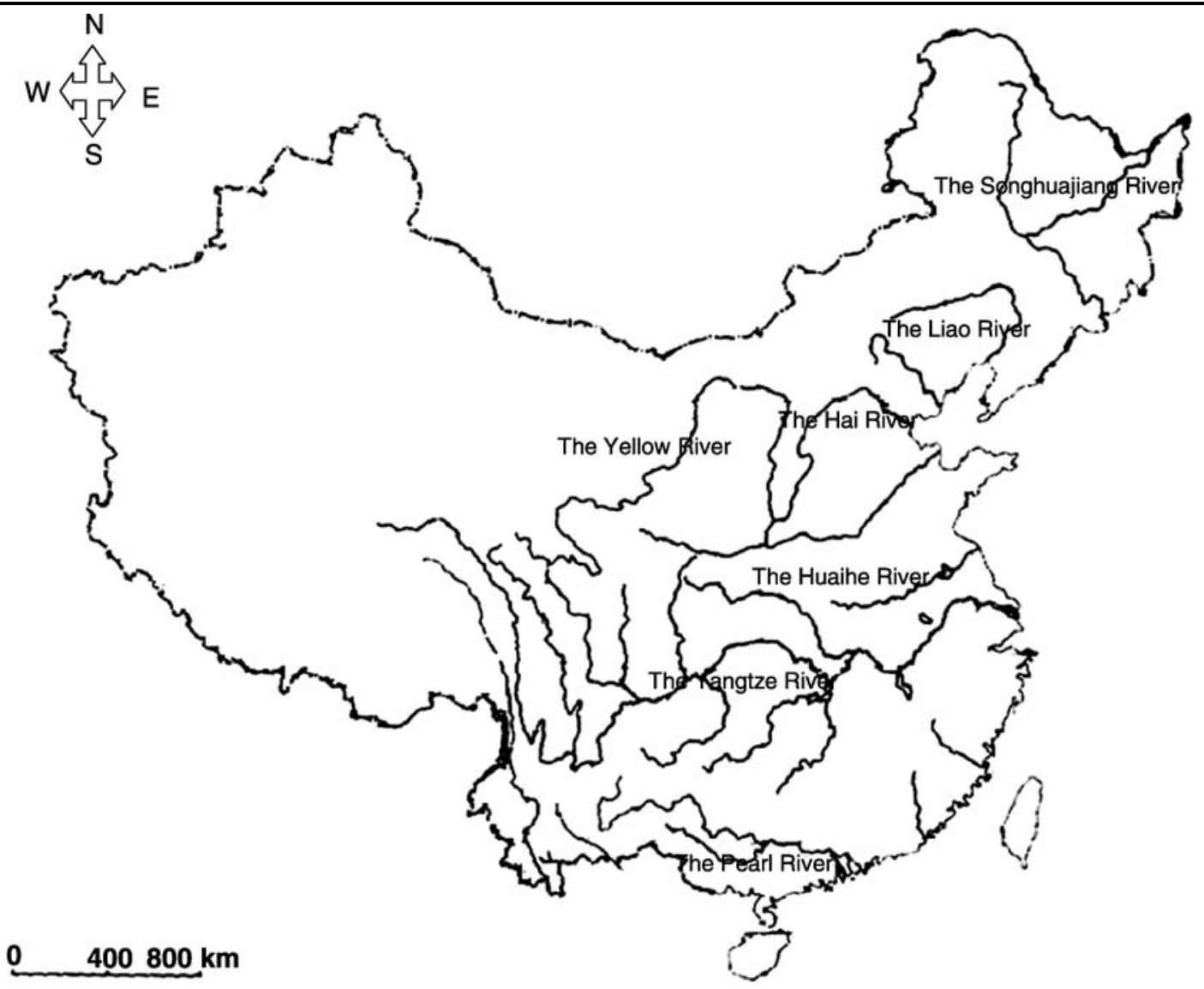

Fig. 1 The map of the seven major river basins in China

by their physical-chemical properties and sediment characteristics (Readman et al. 1984; Mitra and Dickhut 1999; Mackay 2001). Owing to their low aqueous solubility and hydrophobic nature, these compounds are strongly adsorbed to the particles associated with the organic compounds of solid phase matrix, which will finally be deposited to the underlying sediments of estuary, lake and marine (Tolosa et al. 2004).

There are seven major river basins in China, which are: the Yangtze River basin, the Yellow River basin, the Pearl River basin, the Liaohe River basin, the Haihe River basin, the Huaihe River basin and the Songhuajiang River basin (Fig. 1). The rapidly developing industrial and agricultural activities, municipal development and the use of chemicals have caused heavy loads of POPs to aquatic system, which have adversely affected the biological organism (Liu et al. 2000; Manz et al. 2001; Fu et al. 2003; Tao et al. 2003; Zhang et al. 2003). As for PAHs, many studies determined concentrations and sources of PAHs in natural waters all over the world (Fernandes et al. 1997; Kim et al. 1999; Manoli and Samara 1999; Soclo et al. 2000; Notar et al. 2001; Maskaoui et al. 2002; Doong and Lin 2004; Luo et al. 2006; Qiao et al. 2006; Guo et al. 2007; Liu et al. 2008). In China, intense industrial and commercial activities in the coastal area caused adverse effects on the aquatic system (Zhang et al. 2007). In the past few decades, numerous studies have been conducted in order to determine the contamination status and the spatial distribution of PAHs in surface waters (Cao et al. 2005; Li et al. 2006; Feng et al. 2007). The major investigations focused on PAHs concentrations of coastal water and sediments (Mai et al. 2001; Zhou and Maskaoui 2003). In addition, PAHs concentration levels of inland rivers in some big cities, such as Tianjin city in northern China and Hangzhou city in southern China, were also investigated (Shi et al. 2005; Zhu et al. 2004).

In this paper, we reviewed the published literature about PAHs concentration levels of main rivers in China and analyzed the distribution characteristics of PAHs in water, sediment and SPM, respectively. Meanwhile, the concentration levels of PAHs in Chinese rivers and some rivers in other countries were compared. The results could give an overview of PAHs in Chinese fresh water system. Furthermore, it could provide strong scientific data support to the technologies and measures on PAHs pollution prevention and treatment for rivers and lakes in China. 


\section{Method Used to Derive PAHs Concentration}

\section{Sources of Data}

The concentration levels of PAHs in different rivers of China were compiled and summarized from the peer-reviewed literature. All available papers investigating PAHs and published from 2000 to 2008 were screened; and relevant papers containing PAHs concentration were reviewed in detail for valid data.

\section{Data Selection Criteria}

For the purpose of ranking data, the regulations are as follows: First, studies described in the literature are conducted according to or on the basis of valid or international accepted, standardized methodology, including US EPA method or modified US EPA methods. Approaches for the determination of PAHs include those using both high performance liquid chromatographic (HPLC) with fluorescence detector or ultraviolet detector, and gas chromatographicmass spectrometry (GC/MS) (US EPA Method 610 2008; Wang et al. 2007). Second, the literature should have a clear description about quality assurance (QA) and quality control (QC). All data are subjected to strict regime of quality control procedures. Replicate samples are examined in PAHs analysis to further monitor the precision of analytical results (Luo et al. 2004). And then, the recovery value should be in agreement with US EPA methodology protocol. Third, the data described in the papers should be representative. The samples should be collected from the typical river cross sections which could represent PAHs concentrations in the overall or part of the rivers. In the literature surveyed, abnormal data concerning sewage channel, drainage area, seriously polluted sites and harbors are ignored, so as to exactly explain the whole PAHs concentration level in the river watershed.

\section{Results and Discussion}

PAHs Concentrations in Water (Dissolved Phase)

A wide range of research about PAHs distribution in rivers and other surface waters in China have been published in the last decade. The concentrations of PAHs in water from the main rivers at different sampling sites were listed in Table 1. Previous studies indicated that 16 PAHs were detectable in many water samples. It could be seen from those studies that the detection rates of low-ring PAHs compounds were usually greater than the high-ring PAHs, with naphthalene being the highest. It could also be found that 3ring and 4-ring PAHs, including fluorene, phenanthrene, anthracene, fluoranthene and pyrene, were the most abundant compounds in all water samples. The detection rates of 5-ring and 6-ring PAHs, including benzo[b]fluoranthene, benzo[k]fluofanthene, benzo[a]pyrene, dibenzo[a,h]anthracene, benzo[ghi]perylene and indeno[1,2,3-cd]pyrene, were much lower. Among the individual PAHs, the dissolved concentration of 2-ring naphthalene in the rivers of Tianjin city was the highest, reaching up to $32.432 \mu \mathrm{g} / \mathrm{L}$ (Cao et al. 2005). For individual 3-ring to 6-ring PAHs, the highest concentration occurred in Liaohe River (Guo et al. 2007), of which pyrene was the highest $(2.463 \mu \mathrm{g} / \mathrm{L})$. Of all the surface water samples, the PAHs concentration in the Pearl River was relatively lower, except for naphthalene, with its mean value of $2.552 \mu \mathrm{g} / \mathrm{L}$ (Luo et al. 2004). As to the other 15 PAHs in the Pearl River, the concentrations were relatively lower than those in other rivers, except for the concentration of phenanthrene $(0.0107 \mu \mathrm{g} / \mathrm{L})$. As for the northern rivers in China, such as the Liaohe River basin and Haihe River basin, concentration of individual PAHs was much higher than that in the southern Chinese rivers, such as the Yangtze River (Feng et al. 2007), the Pearl River (Luo et

Table 1 The statistical summary of $\Sigma$ PAHs concentration in surface water of Chinese rivers $(\mu \mathrm{g} / \mathrm{L})$

\begin{tabular}{|c|c|c|c|c|c|c|}
\hline Sampling sites & $\begin{array}{l}\text { Sample } \\
\text { number }\end{array}$ & $\begin{array}{l}\text { Minimum } \\
\text { concentration }\end{array}$ & $\begin{array}{l}\text { Maximum } \\
\text { concentration }\end{array}$ & $\begin{array}{l}\text { Mean } \\
\text { concentration }\end{array}$ & $\begin{array}{l}\text { 90th } \\
\text { percentile }\end{array}$ & References \\
\hline Jiulong River, Estuary & 17 & 6.96 & 26.9 & 17.062 & 24.820 & Maskaoui et al. (2002) \\
\hline Surface water, Hangzhou & 17 & 0.989 & 9.663 & 3.717 & 7.123 & Chen et al. (2004) \\
\hline Gaoping River, Taiwan & 48 & 0.01 & 9.4 & 0.43 & & Doong and Lin (2004) \\
\hline The Pearl River, Delta & 12 & 0.691 & 6.458 & 2.715 & 6.335 & Luo et al. (2004) \\
\hline Macao habor & 6 & 0.691 & 6.458 & 3.941 & 6.458 & Luo et al. (2004) \\
\hline Tonghui River, Beijing & 16 & 0.193 & 2.651 & 0.762 & & Zhang et al. (2004) \\
\hline The Rivers, Tianjin & 10 & 0.058 & 1.060 & 0.259 & 1.0123 & Shi et al. (2005) \\
\hline The Qiantangjiang River & 180 & 0.070 & 1.844 & 0.283 & & Chen et al. (2007) \\
\hline The Yangtze River & 11 & 0.242 & 6.235 & 1.452 & 5.605 & Feng et al. (2007) \\
\hline The Liaohe River & 16 & 0.946 & 13.449 & 6.445 & 13.060 & Guo et al. (2007) \\
\hline The Yellow River & 26 & 0.144 & 2.361 & 0.662 & 1.664 & Sun et al. (2008) \\
\hline
\end{tabular}




\begin{tabular}{|c|c|c|c|c|c|c|c|}
\hline Medium & Sampling sites & $\begin{array}{l}\text { Sample } \\
\text { number }\end{array}$ & $\begin{array}{l}\text { Minimum } \\
\text { concentration }\end{array}$ & $\begin{array}{l}\text { Maximum } \\
\text { concentration }\end{array}$ & $\begin{array}{l}\text { Mean } \\
\text { concentration }\end{array}$ & $\begin{array}{l}\text { 90th } \\
\text { percentile }\end{array}$ & References \\
\hline \multirow[t]{7}{*}{ SPM } & Macao harbor & 6 & 0.093 & 0.256 & 0.183 & 0.256 & Luo et al. (2004) \\
\hline & The Rivers, Tianjin city & 10 & 0.938 & 46.3 & 12.846 & 43.02 & Shi et al. (2005) \\
\hline & The Pearl River Delta & 21 & 0.442 & 16.489 & 1.659 & 1.797 & Luo et al. (2006) \\
\hline & Surface waters, Hebei Province & 37 & 0.60 & 171.9 & 17.3 & & Bai et al. (2007) \\
\hline & The Yangtze River & 9 & 0.095 & 8.798 & 3.556 & 8.798 & Feng et al. (2007) \\
\hline & The Liaohe River watershed & 16 & 0.318 & 238.52 & 21.725 & 100.895 & Guo et al. (2007) \\
\hline & The Yellow River & 26 & 0.507 & 10.51 & 4.101 & 8.860 & Sun et al. (2008) \\
\hline \multirow[t]{13}{*}{ sediment } & Jiulong River Estuary & 9 & 0.059 & 1.177 & 0.334 & 1.177 & Maskaoui et al. (2002) \\
\hline & Surface water, Hangzhou & 11 & 0.133 & 7.343 & 1.557 & 6.471 & Chen et al. (2004) \\
\hline & Gaoping River, Taiwan & 48 & 0.001 & 0.356 & 0.081 & & Doong and Lin (2004) \\
\hline & Tonghui River,Beijing & 16 & 0.127 & 0.928 & 0.540 & & Zhang et al. (2004) \\
\hline & The Rivers, Tianjin & 9 & 3.41 & 346 & 59.967 & 346 & Shi et al. (2005) \\
\hline & The Huaihe River & 18 & 0.031 & 1.008 & 0.294 & 0.852 & He and Yan (2006) \\
\hline & The Pearl River Delta & 9 & 0.189 & 0.637 & 0.368 & 0.627 & Luo et al. (2006) \\
\hline & The Qiantangjiang River & 38 & 0.091 & 0.614 & 0.313 & & Chen et al. (2007) \\
\hline & The Yangtze River & 30 & 0.072 & 3.995 & 1.335 & & Feng et al. (2007) \\
\hline & The Liaohe River watershed & 12 & 0.062 & 0.841 & 0.287 & 0.746 & Guo et al. (2007) \\
\hline & The Haihe River & 13 & 0.775 & 255.372 & 27.074 & 163.168 & Jiang et al. (2007) \\
\hline & The Songhuajiang River & 9 & 0.107 & 20.331 & 3.789 & 20.331 & Lu et al. (2007) \\
\hline & The Yellow River & 26 & 0.016 & 1.358 & 0.182 & 0.735 & Sun et al. (2008) \\
\hline
\end{tabular}

al. 2004) and the Gaoping River in Taiwan (Doong and Lin 2004).

Geographical distribution of dissolved $\Sigma$ PAHs from the major rivers was shown in Table 1 . The concentration of $\Sigma$ PAHs in Jiulong River was the highest, ranging from 6.96 to $26.9 \mu \mathrm{g} / \mathrm{L}$, with a mean value of $17.062 \mu \mathrm{g} / \mathrm{L}$ (Maskaoui et al. 2002). The $\Sigma$ PAHs concentration in Liaohe River (Guo et al. 2007), Macao Harbor (Luo et al. 2004) and surface waters in Hangzhou city (Chen et al. 2004) were also higher than those in other rivers, with a mean value of $6.445 \mu \mathrm{g} / \mathrm{L}$, $3.941 \mu \mathrm{g} / \mathrm{L}$ and $3.717 \mu \mathrm{g} / \mathrm{L}$, respectively. It might be probably caused by the well-developed economy and large sewage discharge around these areas.

\section{PAHs Concentrations in SPM}

Suspended particulate matter (SPM) is the most active absorbent of PAHs in water bodies. Because of its complicated composition, it can adsorb the organic pollutants in water, moreover, the adsorbed PAHs can also be transferred to the sediments through settlement process. At the same time, SPM may be generated from the sediment's re-suspension. As a result, SPM in the water body plays an important role in PAHs transportation in aquatic multimedia and reflects the PAHs contamination status. However, data on the PAHs dis- tribution in SPM are much less than those in sediment and in water dissolved phases.

Based on the available data (Table 2), it could be observed that 2-ring to 6-ring PAHs were all detectable in SPM samples, while 3-ring and 4-ring PAHs (acenaphthylene, acenaphthene, fluorene, phenanthrene, anthracene) were more abundant. In general, 6-ring PAHs, such as dibenzo[a,h]anthracene, benzo[ghi]perylene and indeno[1,2,3-cd]pyrene, were detected at higher level and the highest concentrations were in Liaohe River, where they were $3.317 \mu \mathrm{g} / \mathrm{g}, 3.358 \mu \mathrm{g} / \mathrm{g}, 2.606 \mu \mathrm{g} / \mathrm{g}$, respectively (Guo et al. 2007). Regarding to individual PAHs in SPM, the concentration level varied in different rivers. The highest concentration of naphthalene $(226.586 \mu \mathrm{g} / \mathrm{g})$ occurred in one tributary near a heavy industrial area (Taizihe River) in Liaohe River (Guo et al. 2007), which dramatically exceeded other sampling sites in the main course of the same river. The highest concentration of phenanthrene was $88.085 \mu \mathrm{g} / \mathrm{g}$, which was in a lake section of the studied river, close to Tianjin city (Bai et al. 2007). For these individual PAHs in SPM, concentrations in tributaries, lakes, bays, harbors, outfalls were higher than those in main course of rivers.

$\Sigma$ PAHs concentration in Macao harbor was the lowest, ranging from 0.0925 to $0.256 \mu \mathrm{g} / \mathrm{g}$, with a mean value of $0.183 \mu \mathrm{g} / \mathrm{g}$ (Luo et al. 2004). The highest $\Sigma$ PAHs concentra- 
tion in SPM occurred also in the Liaohe River, ranging from 0.3175 to $238.519 \mu \mathrm{g} / \mathrm{g}$, with a mean of $21.725 \mu \mathrm{g} / \mathrm{g}$, followed by rivers in Hebei province in northern China (mean of $17.3 \mu \mathrm{g} / \mathrm{g}$ ) and in Tianjin city (mean of $12.846 \mu \mathrm{g} / \mathrm{g}$ ), respectively. As a result, $\Sigma$ PAHs concentrations in northern regions of China were higher than those in the southern regions of China. The difference should be due to more coal combustion and more heavy industries in north area, such as in Liaohe River basin and around Tianjin city.

\section{PAHs Concentrations in Sediments}

Sediment, as the main destination of PAHs in aquatic environment, reflects a longer-time-period pollution status. Because of the low solubility, most of PAHs could be found in sediment. Adsorbed PAHs may release to water phase and become the secondary contamination source. Surveys on PAHs concentrations in sediment may provide basic data for further ecological risk assessment to aquatic organisms.

As shown in Table 2, PAHs in sediment were mainly dominated by 4-ring and 5-ring PAHs, while concentrations of 2-ring and 3-ring PAHs were relatively lower. Among different water bodies, PAHs concentration in sediments of port, gulf, river estuary and tributaries were higher than those in the main course of rivers. In comparison, PAHs concentration in SPM at the same sampling site of a river was much larger than that in sediment (Luo et al. 2006; Feng et al. 2007; Sun et al. 2008). For one thing, the total organic carbon (TOC) in SPM is possibly higher than that in sediment (Feng et al. 2007); For another, sediment can re-suspend and become SPM, releasing certain amount of organic pollutants into water phase (Yang et al. 2008).

Of all the surveyed rivers, the highest concentration of $\Sigma$ PAHs concentration occurred in those around Tianjin city and as high as $346 \mu \mathrm{g} / \mathrm{g}$, with a mean value of $59.967 \mu \mathrm{g} / \mathrm{g}$ (Shi et al. 2005), followed by the Haihe River, whose $\Sigma$ PAHs concentration ranged from $0.775 \mu \mathrm{g} / \mathrm{g}$ to $255.372 \mu \mathrm{g} / \mathrm{g}$, with a mean value of $27.074 \mu \mathrm{g} / \mathrm{g}$ (Jiang et al. 2007). Some rivers in northern China, such as the Songhuajiang River in Heilongjiang Province and the Tonghui River in Beijing city, PAHs concentrations in sediments were also at higher level, whose mean $\Sigma$ PAHs concentrations were $3.789 \mu \mathrm{g} / \mathrm{g}, 0.54 \mu \mathrm{g} / \mathrm{g}$, respectively. Rivers in southern China, such as the Pearl River, the Qiantangjiang River, the Gaoping River in Taiwan and the Jiulong River, PAHs concentrations in sediments were lower than those in northern rivers, except for a few sampling sites. Distribution pattern of PAHs in sediment was similar to that in surface water and in SPM.

\section{Ranking PAHs Concentration in Rivers of the World}

Compared with other contaminated rivers in the world (Table 3), the PAHs concentrations in water dissolved phase of Chinese rivers were much higher than those in Seine River (Fernandes et al. 1997), Mississippi River (Mitra and Bianchi 2003) and Susquehanna River (Ko et al. 2007), some of which even exceeded 100 folds. The results indicated that level of PAHs in water phase of Chinese rivers was higher. It may possibly because of the intense industrial and commercial activities in the studied area in the past few years, which could result in the high loads of PAHs. However, PAHs concentrations in most of SPM samples from Chinese rivers were close to those in Seine River and Mississippi River, except those from Liaohe River (ranging from $0.318-238.52 \mu \mathrm{g} / \mathrm{g}$; mean $=21.725 \mu \mathrm{g} / \mathrm{g}$ ) and from the rivers in Tianjin area (ranging from $0.938-46.3 \mu \mathrm{g} / \mathrm{g}$; mean $=128.46 \mu \mathrm{g} / \mathrm{g}$ ). For those rivers in southern China, such as the Pearl River, PAHs concentration level in SPM was similar to those of Seine River and Mississippi River, only slightly higher than that in York River (Countway et al. 2003).

As for the PAHs level in sediment from Chinese rivers and other rivers in the world, most rivers in China, including the Yellow River, the Pearl River and rivers in Hangzhou city, were in the middle position. The concentration level of PAHs was close to rivers such as the River estuaries in Malaysia (Zakaria et al. 2002), Kyeonggi Bay in Korea (Kim et al. 1999), Santander Bay in Spain and Susquehanna River in USA (Viguri et al. 2002; Ko et al. 2007). The highest $\Sigma$ PAHs concentration in sediment occurred also in China, i.e., in the rivers around Tianjin city (ranging from 3.41 to $346 \mu \mathrm{g} / \mathrm{g}$, mean $=59.967 \mu \mathrm{g} / \mathrm{g}$ ) (Shi et al. 2005).

On the whole, ranking concentration levels of PAHs in rivers of the world, PAHs level in water dissolved phase in Chinese rivers was a little higher than those in other countries. While in SPM and sediment, PAHs level in Chinese rivers was similar to those rivers in other countries. On the one hand, Chinese rivers are polluted by PAHs to some extent. On the other hand, from the cumulative effects of PAHs in sediment, there is no significant difference between Chinese rivers and the rest of the world.

\section{Spatial Distribution of PAHs}

There were significant differences among $\Sigma$ PAHs concentration in water, SPM and sediment from seven major river basins in China (Fig. 2). For water, the mean concentration of PAHs in Liaohe River basin was the highest (mean = $6.445 \mu \mathrm{g} / \mathrm{L}$ ) and that in Haihe River was the lowest (mean = $0.259 \mu \mathrm{g} / \mathrm{L}$ ). For SPM, the mean concentration of PAHs in Liaohe River basin was the highest (mean $=21.725 \mu \mathrm{g} / \mathrm{g}$ ), followed by that in Haihe River basin (mean $=12.846 \mu \mathrm{g} / \mathrm{g}$ ), and Yellow River basin $($ mean $=4.101 \mu \mathrm{g} / \mathrm{g}$ ). For sediment, the mean concentration of PAHs in Haihe River basin was the highest $($ mean $=27.074 \mu \mathrm{g} / \mathrm{g}$ ), followed by the Songhuajiang River $($ mean $=3.789 \mu \mathrm{g} / \mathrm{g}$ ). Higher PAHs concentra- 
Table 3 Concentrations of PAHs in water, SPM and sediment from different rivers in the world

\begin{tabular}{|c|c|c|c|c|c|}
\hline \multirow[t]{2}{*}{ Phases } & \multirow{2}{*}{$\begin{array}{l}\text { Sampling } \\
\text { sites }\end{array}$} & \multirow{2}{*}{$\begin{array}{l}\text { Sample } \\
\text { number }\end{array}$} & \multicolumn{2}{|c|}{$\Sigma$ PAHs $(\mu \mathrm{g} / \mathrm{L} ; \mu \mathrm{g} / \mathrm{g})^{\mathrm{a}}$} & \multirow[t]{2}{*}{ References } \\
\hline & & & Range & Mean & \\
\hline \multirow[t]{8}{*}{ Water } & Seine River, France & 6 & $0.004-0.036$ & 0.02 & Fernandes et al. (1997) \\
\hline & Mississippi River, USA & 4 & $0.006-0.069$ & 0.041 & Mitra and Bianchi (2003) \\
\hline & Surface waters, Hangzhou China & 17 & $0.989-9.663$ & 3.717 & Chen et al. (2004) \\
\hline & Gaoping River, China & 48 & $0.01-9.4$ & 0.43 & Doong and Lin (2004) \\
\hline & Rivers in Tianjin, China & 10 & $0.058-1.060$ & 0.259 & Shi et al. (2005) \\
\hline & Liaohe River, China & 16 & $0.946-13.449$ & 6.445 & Guo et al. (2007) \\
\hline & Susquehanna River, USA & 36 & $0.017-0.15$ & 0.067 & Ko et al. (2007) \\
\hline & The Yellow River, China & 26 & $0.144-2.361$ & 0.662 & Sun et al. (2008) \\
\hline \multirow[t]{7}{*}{ SPM } & Seine River, France & 11 & $1-14$ & 5 & Fernandes et al. (1997) \\
\hline & York River estuary, US & 20 & $0.002-0.123$ & 0.02 & Countway et al. (2003) \\
\hline & Mississippi River, US & 18 & $1.3-7$ & & Mitra and Bianchi (2003) \\
\hline & The Rivers, Tianjin, China & 10 & $0.938-46.3$ & 12.846 & Shi et al. (2005) \\
\hline & Pearl River Delta, China & 21 & $0.442-16.489$ & 1.659 & Luo et al. (2006) \\
\hline & Liaohe River basin, China & 16 & $0.318-238.52$ & 21.725 & Guo et al. (2007) \\
\hline & The Yellow River, China & 26 & $0.507-10.51$ & 4.101 & Sun et al. (2008) \\
\hline \multirow[t]{10}{*}{ Sediment } & Kyeonggi Bay, Korea & 24 & $0.009-1.4$ & 0.12 & Kim et al. (1999) \\
\hline & Santander Bay, Spain & 16 & $0.02-344.6$ & & Viguri et al. (2002) \\
\hline & Malaysia Rivers & 25 & $0.004-0.924$ & & Zakaria et al. (2002) \\
\hline & Surface waters, Hangzhou, China & 11 & $0.133-7.343$ & 1.557 & Chen et al. (2004) \\
\hline & Gaoping River, China & 48 & $0.001-0.356$ & 0.081 & Doong and Lin (2004) \\
\hline & The Rivers, Tianjin, China & 9 & $3.41-346$ & 59.967 & Shi et al. (2005) \\
\hline & The Pearl River, China & 9 & $0.189-0.637$ & 0.368 & Luo et al. (2006) \\
\hline & Liaohe River, China & 12 & $0.062-0.841$ & 0.287 & Guo et al. (2007) \\
\hline & Susquehanna River, USA & 36 & & 3 & Ko et al. (2007) \\
\hline & The Yellow River, China & 26 & $0.016-1.358$ & 0.182 & Sun et al. (2008) \\
\hline
\end{tabular}

${ }^{\mathrm{a}}$ Concentration of water: $\mu \mathrm{g} / \mathrm{L}$; concentration of sediment and SPM: $\mu \mathrm{g} / \mathrm{g}$

Fig. 2 Geographic distribution of $\Sigma$ PAHs among the seven major river basins in China. (The $\Sigma$ PAHs concentrations used in the figure were the mean values obtained from statistical analysis. Concentration unit of water was $\mu \mathrm{g} / \mathrm{L}$; concentration unit of SPM and sediment was $\mu \mathrm{g} / \mathrm{g}$. The symbol "**" implies a non-available value)

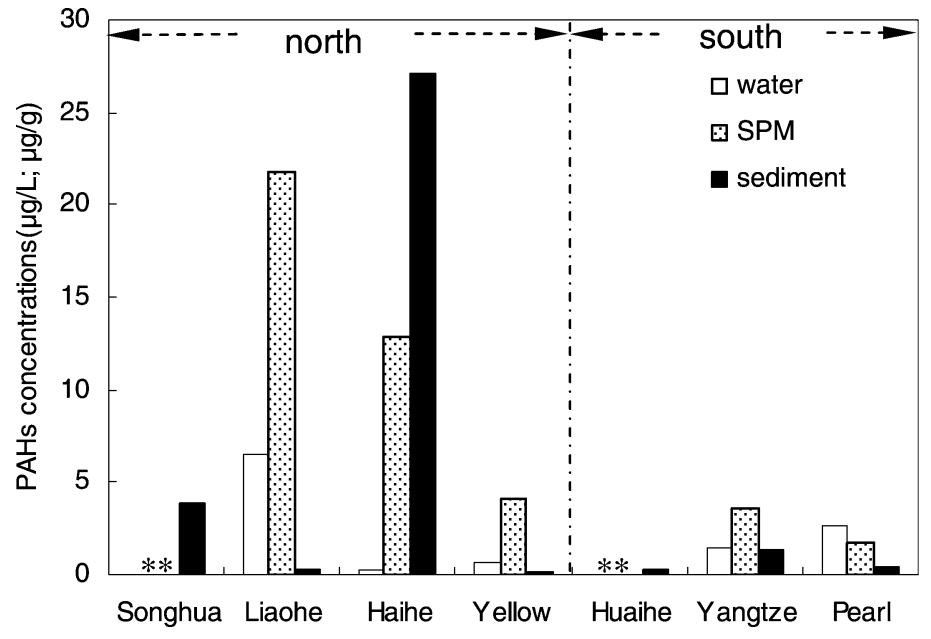

Springer 
tions occurred mostly in north China ( $p<0.05$, significant at the $95 \%$ confidence level). The geographic distribution also showed that the more contaminated river sites occurred mainly in Liaohe River, Haihe River, and Songhuajiang River in northern China. The northern rivers distribute in some big industrial cities such as Tianjin city, Beijing city and Shenyang city. For example, the Liaohe River basin in northern China is the important industrial bases with oil, chemical and steel factories, approximately 2074 million tons of industrial and domestic wastewater are discharged annually into the Liaohe River catchment (SEPA of China 2004). For Tianjin city in northern China, which has a population of 10 million, is highly polluted with the development of industry and rapid urbanization. Industry and automobiles are two major sources of PAHs pollution. The industrial corporation burn 15 million tons of coal per year and discharge 180 million tons of wastewater (Tianjin Environmental Protection Bureau 2001), which lead to the high level of PAHs concentration in the rivers (such as Haihe River basin) of Tianjin area. While in southern China, there are less heavy industrial bases than those in northern China. Besides, due to the climate difference between north and south, the lack of winter-heating system in southern China also result in less coal combustion wastes. Parent PAHs have both natural (plant debris, forest and prairie fires) and anthropogenic sources (fossil fuel combustion, etc.). Incomplete combustion of fossil fuels is always treated as a major production process for PAHs. Therefore, from the sources of these compounds, the PAHs concentration level in southern China is relatively lower than the northern China.

\section{Initial Ecological Risk Assessment}

Ecological risk assessment has been developed from singlespecies toxicity test to multi-species toxicity test, then to ecological risk models. In order to assess the potential ecological risk of PAHs to aquatic organism in major rivers of China, the quotient approach was applied to assess the initial ecological risk of PAHs. Quotient approach has been used to illustrate the risk characterization of target compounds (Solomon et al. 2000; Brain et al. 2006). The aquatic species, which exist widely in the Chinese rivers were selected as the ecological receptors, including phytoplankton, zooplankton, invertebrate, fish, etc. According to the selected ecological receptors and the toxic data from the references, the hazard quotients (hazard quotients,HQ) of some potential chemicals were calculated, followed the formulation as follows:

$\mathrm{HQ}=\frac{\mathrm{C}_{\text {exposure }}}{\mathrm{TRV}}$,

where $\mathrm{C}_{\text {exposure }}$ is the environmental concentration (assumed as exposure concentration) of selected PAHs, TRV is the toxicity reference value (toxicity reference value, TRV) of

\begin{tabular}{lll} 
Table 4 Ecological criteria of PAHs in water and sediment \\
\hline PAHs & Water $(\mu \mathrm{g} / \mathrm{L})$ & Sediment $(\mu \mathrm{g} / \mathrm{g})$ \\
\hline naphthalene & 490 & 0.176 \\
acenaphthylene & $\mathrm{NA}$ & $\mathrm{NA}$ \\
acenaphthene & 23 & $\mathrm{NA}$ \\
fluorene & 11 & 0.077 \\
phenanthrene & 30 & 0.042 \\
anthracene & 0.3 & 0.057 \\
fluoranthene & 6.16 & 0.111 \\
pyrene & 7 & 0.053 \\
benzo[a]anthracene & 34.6 & 0.032 \\
chrysene & 7 & 0.057 \\
benzo]b]fluoranthene & $\mathrm{NA}$ & $\mathrm{NA}$ \\
benzo[k]fluofanthene & $\mathrm{NA}$ & $\mathrm{NA}$ \\
benzo[a]pyrene & 0.014 & 0.032 \\
dibenzo[a,h]anthracene & 5 & 0.033 \\
benzo[ghi]perylene & $\mathrm{NA}$ & $\mathrm{NA}$ \\
indeno[1,2,3-cd]pyrene & $\mathrm{NA}$ & $\mathrm{NA}$ \\
$\Sigma$ PAHs & $\mathrm{NA}$ & 4 \\
\hline & &
\end{tabular}

NA: not available

that PAHs, HQ is hazard quotient. In principle, HQ $>1.0$ indicates that the PAHs might pose potential risk to ecosystems, while $\mathrm{HQ}<1.0$ indicates that the risk was relatively lower. The larger HQ ratio means the higher ecological risk.

The concentrations of PAHs in water and sediment were first sorted out and statistically analyzed as mentioned earlier. Some abnormal data, which could not exactly explain the whole PAHs distribution in certain rivers were eliminated. Moreover, the ecological criteria toxicity data of PAHs in fresh water and sediment for the protection of aquatic life were collected from relative literature (Smith et al. 1996; MacDonald et al. 2000; TNRCC 2001). Thereafter, PAHs levels with national and international guidelines for the protection of aquatic life were summarized in Table 4. Based on the PAHs exposure concentrations in Chinese rivers discussed above and the toxicity reference values of individual PAHs, the quotients were calculated for each of the 16 PAHs. The results showed that the HQs for 16 individual PAHs in water were less than 1.0 except for anthracene in some sampling sites, i.e., in Liaohe River $($ mean $=3.2)$, in rivers from Hangzhou city $($ mean $=0.7)$ and in Jiulong River (mean $=2.0$ ). While in sediments, HQs of 6 PAHs, including phenanthrene, fluoranthene, pyrene, benzo[a]anthracene, chrysene and benzo[a]pyrene, were above 1.0. To sum up, the ecological risk of PAHs in Chinese rivers to aquatic organisms was relatively low. Whereas it also could be easily observed that HQs of 7 PAHs, including phenanthrene, anthracene, fluoranthene, pyrene, benzo[a]anthracene, chrysene, benzo[a]pyrene were 
higher than 1.0 in some dissolved phase samples and sediment samples. Therefore, these PAHs were screened as the potential threat to aquatic environment. Further ecological risk assessment of these screened PAHs needs to be carried out in the near future.

\section{Conclusions}

PAHs occurred widely in Chinese rivers. In aquatic multimedia, low-ring PAHs were dominant in water and highring PAHs were dominant in SPM and in sediment. In general, PAHs concentrations in rivers from the northern China was higher than those from the southern China and highest PAHs concentrations occurred in Liaohe River and in rivers around Tianjin Area, even compared with rivers in the world. Among the 16 PAHs in Chinese rivers, phenanthrene, anthracene, fluoranthene, pyrene, benzo[a]anthracene, chrysene, benzo[a]pyrene were screened using quotient method. These PAHs might have potential ecological risk to aquatic organisms.

Acknowledgements This study was supported by the National Basic Research Program of China (2007CB407304), the National Natural Science Foundation of China (20737003) and Ministry of Environmental Protection (200709034).

\section{References}

Bai YJ, Liu WX, Tao S et al (2007) Distribution of PAHs in surface waters of Hebei Province. Acta Sci Circumst 27(8):1364-1369 (in Chinese)

Brain RA, Sanderson H, Sibley PK et al (2006) Probabilistic ecological hazard assessment: Evaluating pharmaceutical effects on aquatic higher plants as an example. Ecotox Environ Safe 64:128-135

Broman D, Na"f C, Rolff C et al (1991) Occurrence and dynamics of polychlorinated dibenzo-p-dioxins and dibenzofurans and polycyclic aromatic hydrocarbons in the mixed surface layer of remote coastal and offshore waters of the Baltic. Environ Sci Technol 25(11):1850-1864

Cao Z, Wang Y, Ma Y et al (2005) Occurrence and distribution of polycyclic aromatic hydrocarbons in reclaimed water and surface water of Tianjin, China. J Hazard Mater 122:51-59

Chen B, Xuan X, Zhu L et al (2004) Distributions of polycyclic aromatic hydrocarbons in surface waters, sediments and soils of Hangzhou City, China. Water Res 38:3558-3568

Chen Y, Zhu L, Zhou R (2007) Characterization and distribution of polycyclic aromatic hydrocarbon in surface water and sediment from Qiantang River, China. J Hazard Mater 141:148-155

Countway RE, Dickhut RM, Canuel EA (2003) Polycyclic aromatic hydrocarbon $(\mathrm{PAH})$ distributions and associations with organic matter in surface waters of the York River, VA Estuary. Org Geochem 34:209-224

Doong RA, Lin YT (2004) Characterization and distribution of polycyclic aromatic hydrocarbon contaminations in surface sediment and water from Gao-ping River, Taiwan. Water Res 38:17331744

Fang MD, Hsieh PC, Ko FC et al (2007) Sources and distribution of polycyclic aromatic hydrocarbons in the sediments of Kaoping river and submarine canyon system, Taiwan. Mar Pollut Bull 54:1179-1189
Feng C, Xia X, Shen Z et al (2007) Distribution and sources of polycyclic aromatic hydrocarbons in Wuhan section of the Yangtze River, China. Environ Monit Assess 133:447-458

Fernandes MB, Sicre MA, Boireau A et al (1997) Polyaromatic hydrocarbon (PAH) distributions in the Seine River and its estuary. Mar Pollut Bull 34:857-867

Fu JM, Mai BX, Sheng GY et al (2003) Persistent organic pollutants in environment of the Pearl River Delta, China: an overview. Chemosphere 52:1411-1422

Gu SH, Kraloveca AC, Christensen ER et al (2003) Source apportionment of PAHs in dated sediments from the Black River, Ohio. Water Res 37:2149-2161

Guo W, He M, Yang Z et al (2007) Distribution of polycyclic aromatic hydrocarbons in water, suspended particulate matter and sediment from Daliao River watershed, China. Chemosphere 68:93-104

He Y, Yan J (2006) Distribution and ecological risk assessment of PAHs in sediments from Huaihe River. Ecol Environ 15(5):949_ 953 (in Chinese)

Jiang B, Zheng HL, Huang GQ et al (2007) Characterization and distribution of polycyclic aromatic hydrocarbon in sediments of Haihe River, Tianjin, China. J Environ Sci 19:306-311

Kim GB, Maruya KA, Lee RF et al (1999) Distribution and sources of polycyclic aromatic hydrocarbons in sediments from Kyeonggi Bay, Korea. Mar Pollut Bull 38:7-15

Ko FC, Baker J, Fang MD et al (2007) Composition and distribution of polycyclic aromatic hydrocarbons in the surface sediments from the Susquehanna River. Chemosphere 66:277-285

Li G, Xia X, Yang Z et al (2006) Distribution and sources of polycyclic aromatic hydrocarbons in the middle and lower reaches of the Yellow River, China. Environ Pollut 144:985-993

Liu M, Baugh PJ, Hutchinson SM et al (2000) Historical record and sources of polycyclic aromatic hydrocarbons in core sediments from the Yangtze Estuary, China. Environ Pollut 110:357-365

Liu Y, Chen L, Zhao J et al (2008) Distribution and sources of polycyclic aromatic hydrocarbons in surface sediments of rivers and an estuary in Shanghai, China. Environ Pollut 154:298-305

Lu JL, Cai B, Hao LB et al (2007) Preliminary study on polycyclic aromatic hydrocarbons in bottom mud from the middle and lower reaches of the second Songhua river. Rock Miner Anal 26(4):325327 (in Chinese)

Luo X, Mai B, Yang Q et al (2004) Polycyclic aromatic hydrocarbons (PAHs) and organochlorine pesticides in water columns from the Pearl River and the Macao harbor in the Pearl River Delta in South China. Mar Pollut Bull 48:1102-1115

Luo XJ, Chen SJ, Mai BX et al (2006) Polycyclic aromatic hydrocarbons in suspended particulate matter and sediments from the Pearl River Estuary and adjacent coastal areas, China. Environ Pollut 139:9-20

MacDonald DD, Ingersoll CG, Berger TA (2000) Development and Evaluation of Consensus-Based Sediment Quality Guidelines for Freshwater Ecosystems. Arch Environ Con Tox 39:20-31

Mackay D (2001) Multimedia environmental models: the fugacity approach, 2nd edn. Lewis, Boca Raton, pp 199-201

Mai B, Fu J, Zhang G et al (2001) Polycyclic aromatic hydrocarbons in sediments from the Pearl river and estuary, China: spatial and temporal distribution and sources. Appl Geochem 16:1429-1445

Manoli E, Samara C (1999) Polycyclic aromatic hydrocarbons in natural waters: sources, occurrence and analysis. Trends Anal Chem 18(6):417-428

Manoli E, Samara C, Konstantinou I et al (2000) Polycyclic aromatic hydrocarbons in the bulk precipitation and surface waters of Northern Greece. Chemosphere 41:1845-1855

Manz M, Wenzel KD, Dietze U et al (2001) Persistent organic pollutants in agricultural soils of central Germany. Sci Total Environ 277:187-198 
Maskaoui K, Zhou JL, Hong HS et al (2002) Contamination by polycyclic aromatic hydrocarbons in the Jiulong River Estuary and Western Xiamen Sea, China. Environ Pollut 118:109-122

Means JC, Wood SG, Hassett JJ et al (1980) Sorption of polynuclear aromatic hydrocarbons by sediments and soils. Environ Sci Technol 14(12):1524-1528

Mitra S, Bianchi TS (2003) A preliminary assessment of polycyclic aromatic hydrocarbon distributions in the lower Mississippi River and Gulf of Mexico. Mar Chem 82:273-288

Mitra S, Dickhut RM (1999) Three-phase modeling of polycyclic aromatic hydrocarbon association with pore-water-dissolved organic carbon. Environ Tox Chem 18(6):1144-1148

Na"f C, Broman D, Pettersen H et al (1992) Flux estimates and pattern recognition of particulate polycyclic aromatic hydrocarbons, polychlorinated dibenzo-p-dioxins, and dibenzofurans in the waters outside various emission sources on the Swedish Baltic coast. Environ Sci Technol 26(7):1444-1457

Nizzetto L, Lohmann R, Gioia R et al (2008) PAHs in air and seawater along a North-South Atlantic transect: trends, processes and possible sources. Environ Sci Technol 42(5):1580-1585

Notar M, Leskovsek H, Faganeli J (2001) Composition, distribution and sources of polycyclic aromatic hydrocarbons in sediments of the Gulf of Trieste, Northern Adriatic Sea. Mar Pollut Bull 42(1):36-44

Qiao M, Wang CX, Huang SB et al (2006) Composition, sources, and potential toxicological significance of PAHs in the surface sediments of the Meiliang Bay, Taihu Lake, China. Environ Int 32:2833

Readman JW, Mantoura RFC, Rhead MM (1984) The physicochemical speciation of polycyclic aromatic hydrocarbons (PAH) in aquatic systems. J Anal Chem 319:126-131

SEPA of China (2004) Tenth-five-year plan of water pollution prevention and control for "Three rivers and three lakes", 1st edn. Chemical Industry Publishing Company, Beijing

Shi Z, Tao S, Pan B et al (2005) Contamination of rivers in Tianjin, China by polycyclic aromatic hydrocarbons. Environ Pollut 134:97-111

Smith SL, MacDonald DD, Keenleyside KA (1996) A preliminary evaluation of sediment quality assessment values for freshwater ecosystems. J Great Lakes Res 22(3):624-638

Soclo HH, Garrigues PH, Ewald M (2000) Origin of polycyclic aromatic hydrocarbons (PAHs) in coastal marine sediments: case studies in Cotonou (Benin) and Aquitaine (France) areas. Mar Pollut Bull 40(5):387-396

Solomon K, Giesy J, Jones P (2000) Probabilistic risk assessment of agrochemicals in the environment. Crop Prot 19:649-655
Sun JH, Wang GL, Chai Y et al (2008) Distribution of polycyclic aromatic hydrocarbons (PAHs) in Henan Reach of the Yellow River, Middle China. Ecotoxicol Environ Saf (in press)

Tao S, Cao HY, Liu WX et al (2003) Fate modeling of phenanthrene with regional variation in Tianjin, China. Environ Sci Technol 37(11):2453-2459

Tao S, Cui YH, Xu FL et al (2004) Polycyclic aromatic hydrocarbons (PAHs) in agricultural soft and vegetables from Tianjin. Sci Total Environ 320(1):11-24

Tianjin Environmental Protection Bureau (2001) Environmental quality report of Tianjin in 1996-2000

TNRCC (2001) guidance for conducting ecological risk assessments at remediation sites in Texas. RG-263

Tolosa I, Mora SD, Sheikholeslami MR et al (2004) Aliphatic and aromatic hydrocarbons in coastal Caspian sea sediments. Mar Pollut Bull 48:44-60

United States Environmental Protection Agency (US EPA) (2008) Method 610: polycyclic aromatic hydrocarbons

Viguri J, Verde J, Irabien A (2002) Environmental assessment of polycyclic aromatic hydrocarbons (PAHs) in surface sediments of the Santander Bay, Northern Spain. Chemosphere 48:157-165

Wang JZ, Guan YF, Ni HG et al (2007) Polycyclic aromatic hydrocarbons in riverine runoff of the Pearl River Delta (China): concentrations, fluxes, and fate. Environ Sci Technol 41:5614-5619

Yang ZF, Feng JL, Niu JF et al (2008) Release of polycyclic aromatic hydrocarbons from Yangtze River sediment cores during periods of simulated resuspension. Environ Pollut 155:366-374

Zakaria MP, Takada H, Tsutsumi S et al (2002) Distribution of polycyclic aromatic hydrocarbons (PAHs) in rivers and estuaries in Malaysia: a widespread input of petrogenic PAHs. Environ Sci Technol 36:1907-1918

Zhang ZL, Hong HS, Zhou JL et al (2003) Fate and assessment of persistent organic pollutants in water and sediment from Minjiang River Estuary, Southeast China. Chemosphere 52:1423-1430

Zhang Z, Huang J, Yu G et al (2004) Occurrence of PAHs, PCBs and organochlorine pesticides in the Tonghui River of Beijing, China. Environ Pollut 130:249-261

Zhang YX, Tao S, Cao J et al (2007) Emission of polycyclic aromatic hydrocarbons in China by county. Environ Sci Technol 41:683687

Zhou JL, Maskaoui K (2003) Distribution of polycyclic aromatic hydrocarbons in water and surface sediments from Daya Bay, China. Environ Pollut 121:269-281

Zhu LZ, Chen BL, Wang J (2004) Pollution survey of polycyclic aromatic hydrocarbons in surface water of Hangzhou, China. Chemosphere 56:1085-1095 